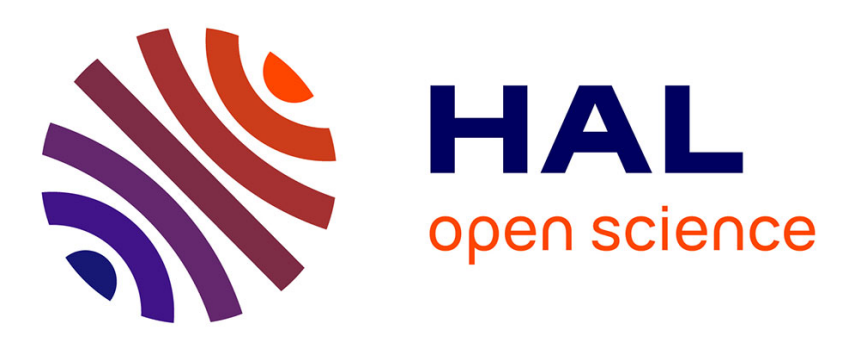

\title{
Conversion of ammonia to hydrazine induced by high frequency ultrasound
}

\author{
Anaelle Humblot, Laurie Grimaud, Audrey Allavena, Prince Nana \\ Amaniampong, Karine de Oliveira Vigier, Tony Chave, Stéphane Streiff, \\ François Jerome
}

\section{To cite this version:}

Anaelle Humblot, Laurie Grimaud, Audrey Allavena, Prince Nana Amaniampong, Karine de Oliveira Vigier, et al.. Conversion of ammonia to hydrazine induced by high frequency ultrasound. Angewandte Chemie International Edition, 2021, 10.1002/anie.202109516 . hal-03365866

\section{HAL Id: hal-03365866 https://hal.science/hal-03365866}

Submitted on 5 Oct 2021

HAL is a multi-disciplinary open access archive for the deposit and dissemination of scientific research documents, whether they are published or not. The documents may come from teaching and research institutions in France or abroad, or from public or private research centers.
L'archive ouverte pluridisciplinaire HAL, est destinée au dépôt et à la diffusion de documents scientifiques de niveau recherche, publiés ou non, émanant des établissements d'enseignement et de recherche français ou étrangers, des laboratoires publics ou privés. 


\title{
Conversion of ammonia to hydrazine induced by high frequency ultrasound
}

\author{
Anaelle Humblot, ${ }^{[\mathrm{a}]}$ Laurie Grimaud, ${ }^{[\mathrm{a}]}$ Audrey Allavena, ${ }^{[\mathrm{a}]}$ Prince N. Amaniampong, ${ }^{[\mathrm{a}]}$ Karine De Oliveira \\ Vigier, ${ }^{[a]}$ Tony Chave, ${ }^{[b]}$ Stéphane Streiff, ${ }^{[c]}$ and François Jérôme ${ }^{*[a]}$
}

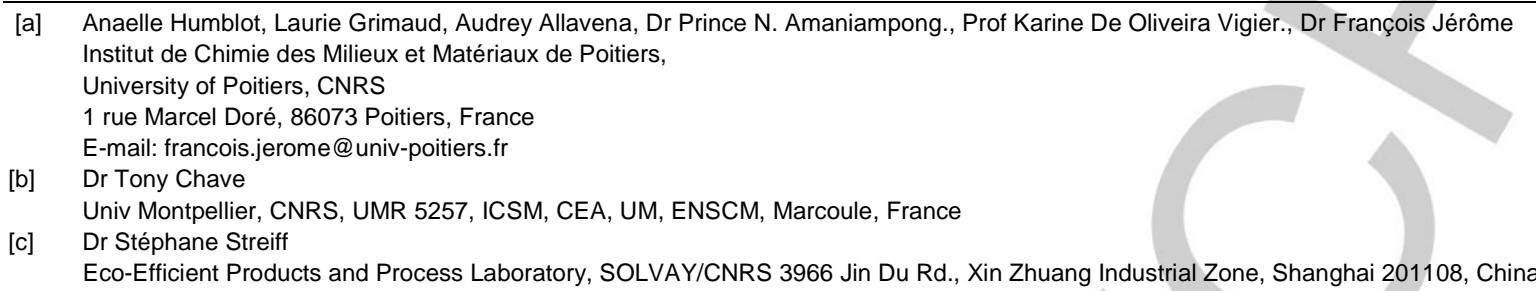

Supporting information for this article is given via a link at the end of the document

\begin{abstract}
Hydrazine is a chemical of outmost importance in our society, either for organic synthesis or energy purpose. The direct conversion of $\mathrm{NH}_{3}$ to hydrazine is highly appealing but it remains a very difficult task because the degradation of hydrazine is thermodynamically more feasible than the cleavage of the $\mathrm{N}-\mathrm{H}$ bond of $\mathrm{NH}_{3}$. As a result, any catalyst capable of activating $\mathrm{NH}_{3}$ will thus unavoidably decompose $\mathrm{N}_{2} \mathrm{H}_{4}$. Here we show that cavitation bubbles, created by ultrasonic irradiation of aqueous $\mathrm{NH}_{3}$ at a high frequency, act as micro-reactors to activate and convert $\mathrm{NH}_{3}$ to $\mathrm{NH}$ species, without assistance of any catalyst, yielding hydrazine at the bubbleliquid interface. The compartmentation of in situ produced hydrazine in the bulk solution, which is maintained close to $30^{\circ} \mathrm{C}$, advantageously prevents its thermal degradation, a recurrent problem faced by previous technologies. This work also points towards a path to scavenge $\cdot \mathrm{OH}$ radicals by adjusting the $\mathrm{NH}_{3}$ concentration.
\end{abstract}

Hydrazine $\left(\mathrm{N}_{2} \mathrm{H}_{4}\right)$ is a chemical of outmost importance in the chemical industry. The hydrazine hydrate market size was 356 million USD in 2015 and is expected to reach 530 million USD in 2024 , mostly boosted by the growing need of our society for the manufacture of polymer foams and agrochemicals, the actual two biggest market shares of hydrazine ${ }^{[1]}$ Besides, the rapid development of hydrazine hydrate fuel cells, ${ }^{[2]}$ nowadays demonstrated with electric vehicles, should also open up new perspectives for hydrazine in the future. Projections showed that hydrazine is one of the chemicals expected to record immense growth prospects across the forecast period of 2020-2030. ${ }^{[3]}$

Hydrazine is industrially produced by partial oxidation of $\mathrm{NH}_{3}$, either with hypochlorite or with peroxide. ${ }^{[4]}$ In the widest spread industrial processes (Bayer-ketazine and peroxide process), hydrazine is trapped in situ under the form of a ketazine, by reaction with a ketone, to prevent its decomposition (Fig. S1). Ketazine is then hydrolyzed to release hydrazine and regenerate the ketone. The direct production of hydrazine from $\mathrm{NH}_{3}$ or $\mathrm{N}_{2} / \mathrm{H}_{2} \mathrm{O}$ is economically and environmentally highly attractive, but it remains a very difficult task. One of the reason stems from the high $\mathrm{N}-\mathrm{H}$ and $\mathrm{N}-\mathrm{N}$ bond dissociation of $\mathrm{NH}_{3}(435 \mathrm{~kJ} / \mathrm{mol})$ and $\mathrm{N}_{2}(946 \mathrm{~kJ} / \mathrm{mol})$, respectively, requiring harsh conditions of temperature and pressure, which are not compatible with the

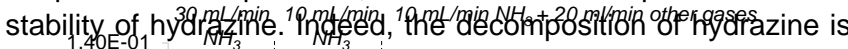
thermodynamically wore favorable $(\Delta G=-150 \mathrm{~kJ} / \mathrm{mol})$ than the$$
\text { 政 }
$$

conversion of $\mathrm{NH}_{3}(\Delta \mathrm{G}=16.5 \mathrm{~kJ} / \mathrm{mol})$ or $\mathrm{N}_{2} / \mathrm{H}_{2} \mathrm{O}(\Delta \mathrm{G}=184$ $\mathrm{kJ} / \mathrm{mol}$ ) to hydrazine, making the accumulation of hydrazine scientifically challenging. ${ }^{[5]}$

Physical activation of the $\mathrm{N}-\mathrm{H}$ and $\mathrm{N}-\mathrm{N}$ bond of $\mathrm{NH}_{3}$ and $\mathrm{N}_{2}$, respectively, at low temperature with electron beam, ${ }^{[6]}$ plasma, ${ }^{[7]}$ light, ${ }^{[8]}$ or by the coupling of these technologies with catalysis such as electrocatalysis for instance have been explored for the synthesis of hydrazine. ${ }^{[5 a, 9]}$ Although fascinating results were reported, the in situ decomposition of hydrazine cannot be avoided, leading to the formation of very diluted feeds of hydrazine (i.e. micromolar).

High frequency ultrasound (HFUS), a technology based on cavitation phenomenon, is gaining more and more interest in the field of chemistry. ${ }^{[10]}$ Due to the extreme conditions of pressures and temperatures existing inside the cavitation bubbles, it was shown by sonoluminescence spectroscopy that gaseous molecules, with high bond dissociation energies such as $\mathrm{N}_{2}, \mathrm{O}_{2}$, $\mathrm{CO}_{2}, \mathrm{CH}_{4}$, can be cleaved inside the cavitation bubbles, leading to the formation of radicals and the occurrence of sonochemical reactions. ${ }^{[11]}$ So far, the activation of $\mathrm{NH}_{3}$ by HFUS has been investigated sporadically, and the rare previous studies were mainly focused on the elimination of $\mathrm{NH}_{3}$ from waste water (by degassing, pyrolysis). ${ }^{[12]}$ In 2017, a pioneer work of Pflieger demonstrated, by sonoluminescence spectroscopy, that $\mathrm{NH}$ species can be formed inside the cavitation bubbles, by subjecting an aqueous solution of $\mathrm{NH}_{3} \quad(0,17 \mathrm{wt} \%)$ to an ultrasonic irradiation at $359 \mathrm{kHz} .{ }^{[13]}$ Inspired by these results, we investigate here the sonochemical conversion of $\mathrm{NH}_{3}$ to $\mathrm{N}_{2} \mathrm{H}_{4}$. Unlike previous works, we show here that by adjusting the temperature of the solution and the concentration of $\mathrm{NH}_{3}$, it was possible to limit the decomposition of hydrazine, a scientific and technological problem faced by previous routes.

In a first set of experiments, $\mathrm{NH}_{3}$ was continuously bubbled (30 $\mathrm{mL} / \mathrm{min}$ ) in $100 \mathrm{~mL}$ of water subjected to an ultrasonic irradiation at $525 \mathrm{kHz}$, with an acoustic power of $0.17 \mathrm{~W} / \mathrm{mL}$. The aqueous solution of $\mathrm{NH}_{3}$ was maintained at $30^{\circ} \mathrm{C}$ using a cooling system coupled to the ultrasonic reactor (Fig. S2). Hydrazine was titrated by spectrophotometry and results were doubly confirmed by HPLC titration (Fig. S3-S7). Hereafter, the formation rate of hydrazine is given with an uncertainty of $5 \%$. 
Figure 1. Influence of gases on the initial formation rate of $\mathrm{N}_{2} \mathrm{H}_{4}(10 \mathrm{ml} / \mathrm{min}$ $\mathrm{NH}_{3}+20 \mathrm{ml} / \mathrm{min}$ gas, $\left.525 \mathrm{kHz}, 0.17 \mathrm{~W} / \mathrm{mL}, 30^{\circ} \mathrm{C}\right)$. All reactions were conducted at atmospheric pressure.

Pleasingly, under these conditions, hydrazine was continuously produced at a rate of $0.12 \mathrm{mmol} . \mathrm{L}^{-1} \cdot \mathrm{h}^{-1}$ (Fig. S8). The dilution of $\mathrm{NH}_{3}$ in gases such as $\mathrm{O}_{2}, \mathrm{~N}_{2}, \mathrm{Ar}$, or He resulted in a decrease of the formation rate of hydrazine (Fig. 1). No correlation was established between the physicochemical properties of the gas (thermal conductivity, heat capacity, etc...) and the formation rate of $\mathrm{N}_{2} \mathrm{H}_{4}$. As a result, we suspect that the formation rate of $\mathrm{N}_{2} \mathrm{H}_{4}$ is more related to the solubility of $\mathrm{NH}_{3}$ in water. To support this claim, aqueous $\mathrm{NH}_{3}$ solutions with different concentrations (from 0.1 to 20 wt\%) were subjected to an ultrasonic irradiation $(525 \mathrm{kHz})$ under air (i.e. no bubbling of $\mathrm{NH}_{3}$ ). The plot of the formation rate of hydrazine as a function of the $\mathrm{NH}_{3}$ concentration is reported in Fig. 2.

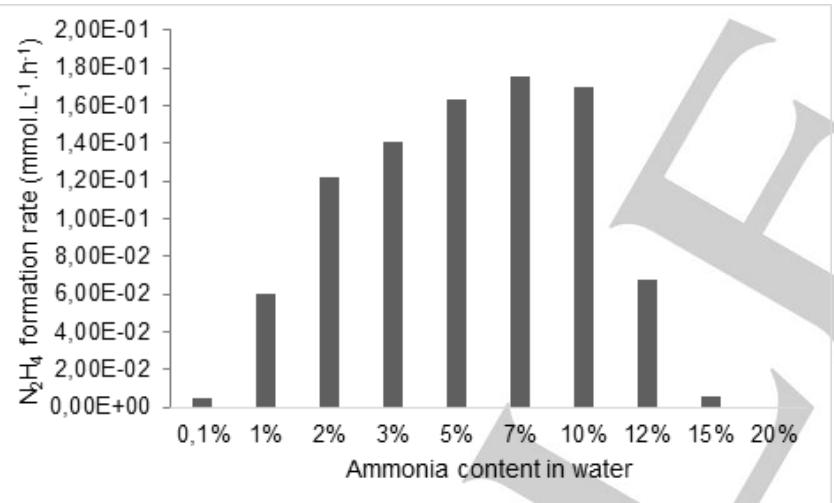

Figure 2. Effect of the $\mathrm{NH}_{3}$ concentration on the formation rate of hydrazine $\left(525 \mathrm{kHz}, 0.17 \mathrm{~W} / \mathrm{mL}, 30^{\circ} \mathrm{C}\right)$.

A volcano-type curve was obtained. The formation rate of hydrazine gradually increased with a concomitant increase of the $\mathrm{NH}_{3}$ concentration from 0.1 to $7 \mathrm{wt} \%$, to reach a maximum of $0.17 \mathrm{mmol} \mathrm{N}_{2} \mathrm{H}_{4} \cdot \mathrm{L}^{-1} \cdot \mathrm{h}^{-1}$ at $7 \mathrm{wt} \% \mathrm{NH}_{3}$. At higher concentration of $\mathrm{NH}_{3}$, the formation rate of hydrazine declined, and was even inhibited at a $\mathrm{NH}_{3}$ concentration over $15 \mathrm{wt} \%$. This result can be understood in terms of thermodynamics. The sonochemical decomposition of $\mathrm{NH}_{3}$ is endothermic. Hence, when the concentration of $\mathrm{NH}_{3}$ inside the cavitation bubbles is increasing, it decreases the maximum temperature and pressure that can be reached inside the cavitation bubbles, thus finally quenching sonochemical reactions. ${ }^{[14]}$
In order to get more insight on the reaction mechanism, we first checked any possible role of the metallic reactor wall (316 L stainless steel) on the hydrazine production. To this end, a similar experiment was conducted by confining the aqueous solution of $\mathrm{NH}_{3}$ (5 wt\%) in a polyethylene flask (material transparent to the ultrasonic waves) immerged into the ultrasonic reactor filled with water. No significant change in hydrazine production rate was observed, ruling out a possible contribution of the metallic reactor wall in the reaction mechanism (Fig. S9-S10). Next, the concentration of hydrazine was plotted as a function of the reaction time $\left(30^{\circ} \mathrm{C}, \mathrm{NH}_{3}\right.$ at 30 $\mathrm{mL} / \mathrm{min}, 0.21 \mathrm{~W} / \mathrm{mL}$ ). Very interestingly, over a period of $20 \mathrm{~h}$, the reaction never plateaued and hydrazine was continuously produced (Fig. 3). At $20 \mathrm{~h}$ of ultrasonic irradiation at $525 \mathrm{kHz}$, the concentration of hydrazine reached $3.3 \mathrm{mmol} / \mathrm{L}$, which is about 1000 times higher than in previously reported works. These results also suggest that the formation rate of hydrazine is faster than its decomposition, which constitute one of the unique examples in the state of the art.

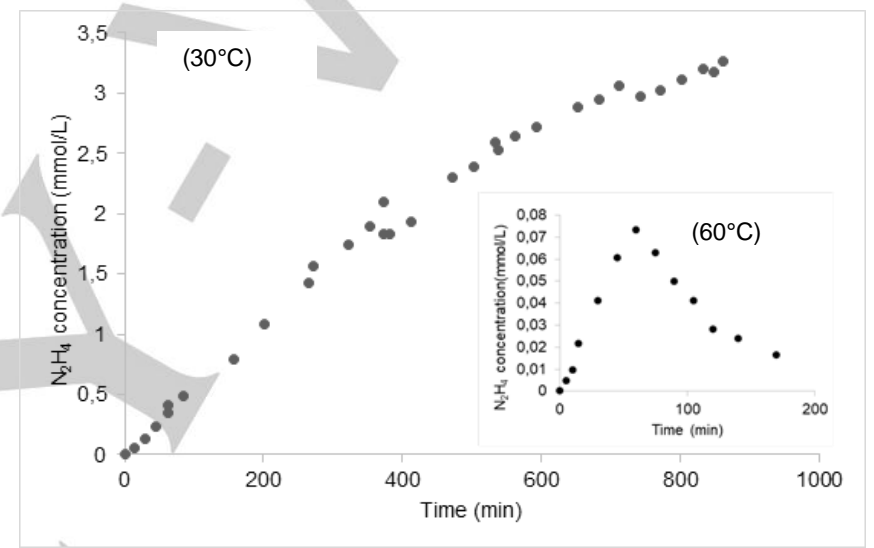

Figure 3. Concentration of hydrazine as a function of the reaction time (bubbling of $\mathrm{NH}_{3}$ at $30 \mathrm{ml} / \mathrm{min}, 525 \mathrm{kHz}, 0.21 \mathrm{~W} / \mathrm{mL}$ ) at $30^{\circ} \mathrm{C}$ and $60^{\circ} \mathrm{C}$.

One of the explanations for this result stems from the low temperature of the aqueous $\mathrm{NH}_{3}$ solution $\left(30^{\circ} \mathrm{C}\right)$, preventing the thermal decomposition of hydrazine. Indeed, under silent conditions, hydrazine was found stable in aqueous $\mathrm{NH}_{3}$ (5 wt\%) at $30^{\circ} \mathrm{C}$, while at $60^{\circ} \mathrm{C}$ a degradation was observed (Fig. S11). To support this claim, the temperature of the ultrasonic reactor was increased from 30 to $60^{\circ} \mathrm{C}$. At $60^{\circ} \mathrm{C}$, the formation of hydrazine remained very low and reached only $0.073 \mathrm{mmol} / \mathrm{L}$ after $60 \mathrm{~min}$, (Fig. 3), confirming the negative impact of the temperature on the hydrazine production. Although high temperatures are reached in the cavitation bubbles, the bulk aqueous solution of $\mathrm{NH}_{3}$ can be maintained at $30^{\circ} \mathrm{C}$, which represents a noticeable advantage of this technology to prevent the thermal degradation of hydrazine.

The second explanation can be understood in terms of $\bullet \mathrm{OH}$ radical scavenging by $\mathrm{NH}_{3}$. It has been previously demonstrated, by sonoluminescence spectroscopy, that ultrasonic irradiation of an aqueous solution of $\mathrm{NH}_{3}$ concomitantly generate $\mathrm{NH}$ and $\bullet \mathrm{OH}$ radicals. ${ }^{[13]} \bullet \mathrm{OH}$ radicals are known to decompose hydrazine. ${ }^{[15]}$ To assess the reactivity of in situ produced $\bullet \mathrm{OH}$ radicals, we first measured the amount of $\mathrm{H}_{2} \mathrm{O}_{2}$ formed, resulting from the recombination of $\bullet \mathrm{OH}$ radicals (Fig. S12, 13). Interestingly, when the concentration of $\mathrm{NH}_{3}$ is over 1 wt\%, no $\mathrm{H}_{2} \mathrm{O}_{2}$ was detected, confirming that $\bullet \mathrm{OH}$ radicals are quickly scavenged in situ (Fig. 
S14). Two scenarios are thus possible: (1) the scavenging of $\bullet \mathrm{OH}$ radicals by $\mathrm{NH}_{3}$, to form $\bullet \mathrm{NH}_{2}$ radical and water, or (2) the scavenging of $\bullet \mathrm{OH}$ radicals by hydrazine, inducing its partial decomposition to $\mathrm{N}_{2}$ and $\mathrm{H}_{2} \mathrm{O}$. To discriminate between these two scenarios, a solution of hydrazine $(0.1 \mathrm{mmol} / \mathrm{L})$ was subjected to an ultrasonic irradiation either with or without $\mathrm{NH}_{3}$. In line with previous reports, without $\mathrm{NH}_{3}$, hydrazine was nearly completely decomposed after only $2 \mathrm{~h}$ of irradiation by in situ produced $\bullet \mathrm{OH}$ radicals (Fig. 4). In contrast, in an aqueous solution of $\mathrm{NH}_{3}$ (5 wt\%), the concentration of hydrazine kept increasing, indicating that $\bullet \mathrm{OH}$ radicals are scavenged by $\mathrm{NH}_{3}$ (Fig.4). A similar behavior was observed with $1 \mathrm{mmol} / \mathrm{L}$ of hydrazine (Fig. S15). These results can be explained in terms of probability. Indeed, the concentration of $\mathrm{NH}_{3}(1-5 \mathrm{wt} \%=0.6-3$ $\mathrm{mol} / \mathrm{L}$ ) is much higher than that of hydrazine. As a result, the probability for the $\bullet \mathrm{OH}$ radical to react with $\mathrm{NH}_{3}$ is much higher than with hydrazine.

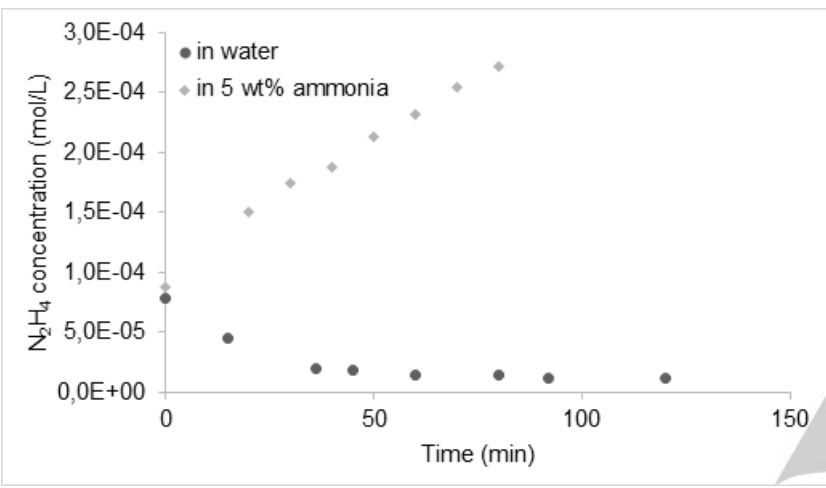

Figure 4. Stability of hydrazine under ultrasonic irradiation with and without $\mathrm{NH}_{3}$ (initial hydrazine concentration $=0.1 \mathrm{mmol} / \mathrm{L}$ in water or in $5 \mathrm{wt} \%$ ammonia, $525 \mathrm{kHz}, 30^{\circ} \mathrm{C}, 0.17 \mathrm{~W} / \mathrm{mL}$ )

From these data, a plausible reaction mechanism can be proposed. During the ultrasonic irradiation, $\mathrm{NH}_{3}$ and vapors of water diffuse within the cavitation bubbles to produce $\mathrm{NH}$ and - $\mathrm{OH}$ radicals as observed elsewhere. ${ }^{[13]} \mathrm{NH}$ species can react either with $\mathrm{NH}_{3}$ to form two $\bullet \mathrm{NH}_{2}$ radicals or with $\mathrm{H}_{2} \mathrm{O}$ to form $\cdot \mathrm{NH}_{2}$ and $\bullet \mathrm{OH}$ radicals. These recombination reactions can occur either inside the cavitation bubbles or at the cavitation bubble-liquid interface. As the amount of $\mathrm{H}_{2} \mathrm{O}$ is 18 times higher than that of $\mathrm{NH}_{3}$ in our reactor (at $5 \mathrm{wt} \% \mathrm{NH}_{3}$ ), we assume that the main reaction taking place for $\mathrm{NH}$ is the reaction with $\mathrm{H}_{2} \mathrm{O}$. On the other hand, and as discussed above, $\bullet \mathrm{OH}$ radicals are rapidly trapped by $\mathrm{NH}_{3}$, the second largest abundant chemical in the HFUS reactor, presumably to form $\bullet \mathrm{NH}_{2}$ radicals and water, a reaction which is thermodynamically favored $(\Delta G=-46$ $\mathrm{kJ} / \mathrm{mol}) .{ }^{[16]}$ In terms of probability, the recombination of $\bullet \mathrm{NH}_{2}$ radicals with $\bullet \mathrm{OH}$ radicals is less likely to occur, as $\bullet \mathrm{OH}$ radicals are rapidly scavenged by $\mathrm{NH}_{3}$. To check this hypothesis, the asobtained aqueous solution was fully analyzed by HPLC, in particular to detect the formation of nitrate. Indeed, it is known that $\bullet \mathrm{OH}$ radical can react with $\bullet \mathrm{NH}_{2}$ radical to form $\mathrm{NH}_{2} \mathrm{OH}$ which is instable and further rapidly convert to nitrate. ${ }^{[17]}$ As expected, with a bubbling of $\mathrm{NH}_{3}(30 \mathrm{~mL} / \mathrm{min})$, the amount of nitrate remained below the detection limit of our apparatus, supporting that the recombination of $\bullet \mathrm{NH}_{2}$ with $\bullet \mathrm{OH}$ is not a dominant reaction. Hence, ${ }^{\bullet} \mathrm{NH}_{2}$ radicals has no other option than to dimerize to form $\mathrm{N}_{2} \mathrm{H}_{4}$.
In an attempt to elucidate whether hydrazine is formed inside the cavitation bubbles or at the bubble liquid interface, phenol was added into the solution as a radical scavenger. Phenol has a high boiling point $\left(182^{\circ} \mathrm{C}\right)$ and a low vapor pressure $(0.2 \mathrm{mmHg}$ at $20^{\circ} \mathrm{C}$ ), making it improbable its diffusion inside the cavitation bubble, as demonstrated in other reports. ${ }^{[18]}$ Hence, phenol is a suitable radical scavenger to selectively trap radicals at the bubble-liquid interface. Interestingly, in the presence of phenol $(0.1 \mathrm{~mol} / \mathrm{L})$ in an aqueous $\mathrm{NH}_{3}$ solution (5 wt\%), no hydrazine was formed, suggesting that hydrazine is more likely to be formed at the bubble-liquid interface. To further support this claim, sodium benzoate was also tested as another radical scavenger, as it reacts slower with radical species than phenol, allowing a better monitoring of the reaction. ${ }^{[16,19]}$ In addition, as a salt, the vapor pressure of sodium benzoate is negligible at $30^{\circ} \mathrm{C}$. As expected, an incremental increase of the amount of sodium benzoate led also a gradual decrease of the amount of hydrazine, confirming the results obtained with phenol (Fig.S16). Altogether, these results strongly suggest that the formation of hydrazine occurred at the bubble-liquid interface. Beside, hydrazine hydrate $(64 \mathrm{wt} \%)$ has a boiling point of $114^{\circ} \mathrm{C}$ and a vapor pressure of $7.5 \mathrm{mmHg}$ at $30^{\circ} \mathrm{C}$. Hence, its diffusion inside the cavitation bubbles is negligible and thus hydrazine dominantly remains compartmented into the bulk solution at $30^{\circ} \mathrm{C}$, where its thermal decomposition is drastically limited. (Fig. $5)$.

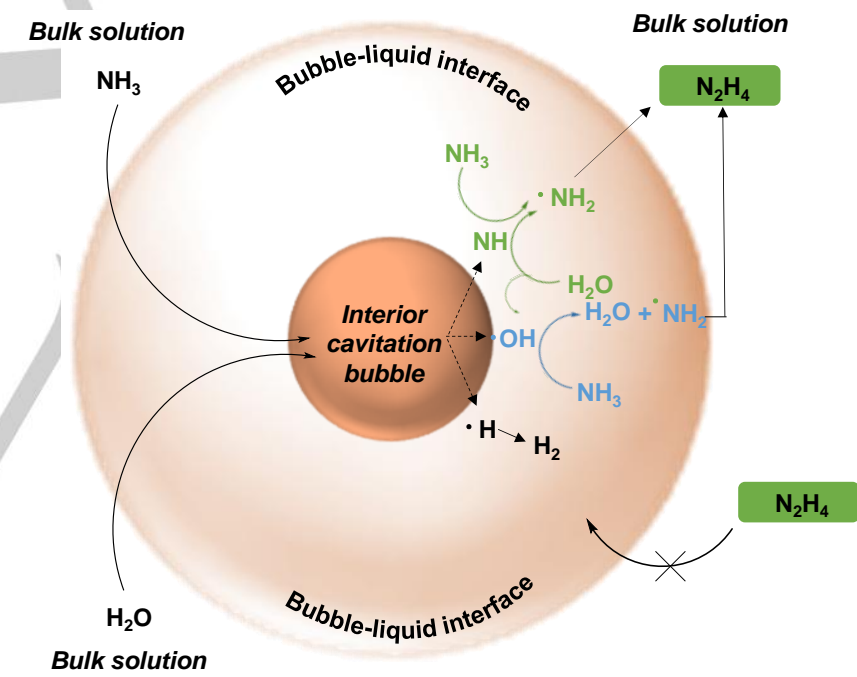

Figure 5. Proposed reaction pathway. For the sake of clarity, only reactions taking place at the cavitation bubble-liquid interface are shown.

As the selectivity to hydrazine is governed by the concentration of $\mathrm{NH}_{3}$ and $\mathrm{N}_{2} \mathrm{H}_{4}$ into the reactor, one may question the maximum concentration of hydrazine this technology may support. Using a simple statistical model, and with the approximations that (1) the rate of each radical reactions is similar and (2) the $\mathrm{NH} / \mathrm{OH}$ ratio is 1 , aqueous solution of hydrazine of 3.5 and 7.3 wt\% could be theoretically obtained with this technology from a 5 and 10 wt\% of aqueous $\mathrm{NH}_{3}$ solution, respectively (more information is provided in the SI, Fig. $\mathrm{S} 17-\mathrm{S} 19)$. If the $\mathrm{NH} / \mathrm{OH}$ ratio now varies from 0.01 to 100 , the $\mathrm{N}_{2} \mathrm{H}_{4}$ is expected to be produced within a concentration range of 2.32-3.91 wt $\%$ and 4.72-8.08 wt $\%$ from a 5 and 10 wt $\%$ of 
aqueous $\mathrm{NH}_{3}$ solution, respectively, which are typical concentrations routinely handled in industry. The highest amount of $\mathrm{N}_{2} \mathrm{H}_{4}$ is obtained at the highest $\mathrm{NH} / \mathrm{OH}$ ratio (Fig. S20). It is noteworthy that at these concentration ranges, and in our conditions (atmospheric pressure and $30^{\circ} \mathrm{C}$ ), the risk of detonation/flammability is very unlikely (no flash point of aqueous hydrazine at these concentrations), water acting as an inerting agent in this case. ${ }^{[20]}$ More information on safety is discussed in the supporting information.

With the reactor design in our hands, we are limited by the low formation rate of $\mathrm{N}_{2} \mathrm{H}_{4}$, making it very long, and even not realistic, the formation of 2-8 wt\% aqueous solution of hydrazine. However, the formation rate of hydrazine could be largely increased by working in a continuous flow reactor, as the acoustic power density will be locally much higher than in our reactor. To demonstrate this possibility, the acoustic power density was varied from 0.1 to $0.23 \mathrm{~W} / \mathrm{mL}$ (Fig. 6). As expected, the formation rate of hydrazine was directly impacted by the acoustic power and the formation rate of hydrazine exponentially increased with the acoustic power. This last result demonstrates that switching from a batch to a continuous flow reactor could be a promising perspective for this work to investigate the conversion of $\mathrm{NH}_{3}$ to more concentrated solutions of hydrazine hydrate, but also to reduce the energy expenditure of this pathway.

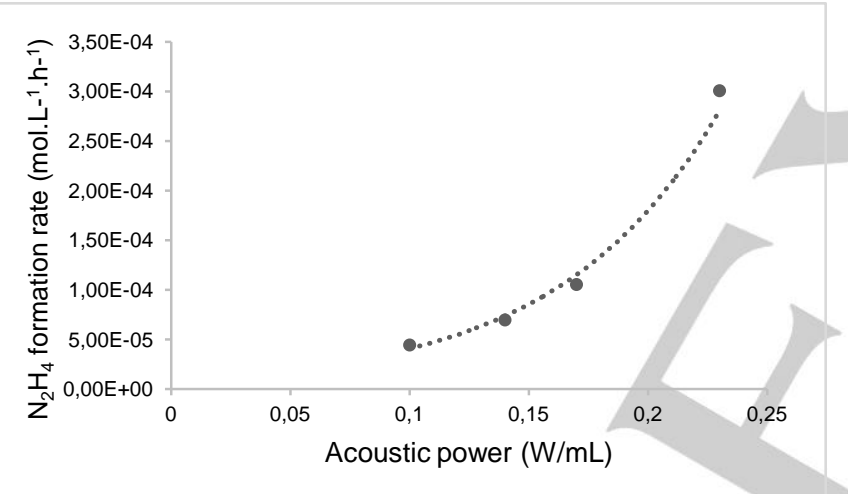

Figure 6. Effect of the absorbed acoustic power on the formation rate of hydrazine $\left(30 \mathrm{ml} / \mathrm{min} \mathrm{NH}_{3}, 525 \mathrm{kHz}, 30^{\circ} \mathrm{C}\right)$.

In conclusion, these preliminary results suggest that high frequency ultrasound is a potential disruptive technology for the direct, salt-free conversion of $\mathrm{NH}_{3}$ to hydrazine. Cavitation bubbles act as micro-reactors to activate $\mathrm{NH}_{3}$, resulting in the formation of $\mathrm{NH}$ species that are further recombined to hydrazine at the bubble-liquid interface. One of the advantage of this technology is the compartmentation of hydrazine into the bulk solution where the temperature is maintained at $30^{\circ} \mathrm{C}$, thus avoiding its thermal degradation, a recurrent problem faced with previous technologies. In addition, we showed that adjusting the concentration of $\mathrm{NH}_{3}$ allowed a rapid scavenging of $\bullet \mathrm{OH}$ by $\mathrm{NH}_{3}$, thus limiting the oxidative degradation of hydrazine at the bubble liquid-interface.

Two perspectives are under investigation in our groups (1) a switch from a batch to a continuous flow reactor to improve the efficiency of this transformation, in particular in terms of reaction time (i.e. energy efficiency), and (2) the exploration of this technology for the activation and utilization of $\mathrm{NH}_{3}$ in organic reactions to produce chemicals with higher added value than $\mathrm{N}_{2} \mathrm{H}_{4}$.

\section{Acknowledgements}

Authors are grateful to the CNRS, the University of Poitiers and the region Nouvelle Aquitaine for the funding of this study. $\mathrm{AH}$ is also grateful to the CNRS for the funding of her PhD. Authors also acknowledge Marie Jérôme for the statistic calculations. YingYing Ma, Bright Kusema (Health Safety and Environment managers from SOLVAY) and emeritus Prof Charles Kappenstein are also acknowledged for the discussion on the safety of hydrazine.

Keywords: Ammonia $\cdot$ Cavitation bubbles $•$ Hydrazine Radicals • Ultrasound

[1] https://www.gminsights.com/industry-analysis/hydrazine-hydratemarket

[2] a) N. V. Reesa, R. G. Compton, Energy Environ. Sci., 2011, 4, 1255 1260 ; b) A. Serov, C.Kwak, Appl. Catal. B: Environ., 2010, 98 (1-2), 1 9.

[3] https://www.transparencymarketresearch.com/hydrazine-market.htm

[4] a) Hiromu Hayashi, Res. Chem. Intermed, 1998, 24 (2), 183-196; b) E. F. Rothgery Hydrazine and its derivatives in Kirk-Othmer Encyclopedia of Chemical Technology, 2004, John Wiley \& Sons, https://doi.org/10.1002/0471238961.0825041819030809.a01.pub2; b) H. Hayashi, Catal. Rev. Sci. Eng., 1990, 32(3). 229-277.

[5] a) F. Wang, J. B. Gerken, D. M. Bates, Y. Jung Kim, S. S. Stahl, J. Am. Chem. Soc., 2020, 142, 12349-12356; b) O. A. Ojelade, S. F. Zaman, Chemical Papers, 2021, 75, 57-65.

[6] H. Bubert, F. W. Froben, J. Phys. Chem., 1971, 76 (6), 769-771.

[7] a) John C. Devins, M. Burton, J. Am. Chem. Soc. 1954, 76, 10, 26182626; b) R. Barker, M. J. Copsey, Nat. Phys. Sci., 1971, 232, 68-69; c) M. Akiyama, K. Aihara, T. Sawaguchi, Masahiko Matsukata, Masakazu Iwamoto, Inter. J. Hydrogen Energy, 2018, 43 (31), 14493-14497; d) J. D. Thornton, P. L. Spedding, Nature, 1967, 213, 1118-1119; e) H. Uyama, T. Nakamura, S. Tanaka, O. Matsumoto, Plasma Chem. Plasma Proc., 1993, 13, 117-131.

[8] a) O. Linnik, H. Kisch, Photochem. Photobiol. Sci., 2006, 5, 938-942; b) X. Chen, N. Li, Z. Kong, W.-J. Ong, X. Zhao, Mater. Horiz., 2018, 5, 927 ; c) C. C. McDonald, H. E. Gunning, J. Chem. Phys., 1955, 23, 532; d) A. J. Medford, M. C. Hatzell, ACS Catal. 2017, 7 (4), 2624-2643; e) H.-R. Park, H.-J. Kim, H.-C. Lee, Bull. Korean Chem. Soc. 1997, 18 (2), 226-229; f) G. N. Schrauzer, T. D. Guth, J. Am. Chem. Soc. 1977, 99 (22), 7189-7193; g) T. Okazaki, H. Hayashi, E. Kawanishiand, Y. Konishi, J. Chem. Eng. Japan, 1982, 15 (4), 318-320.

[9] P. Saha, S. Amanullah, A. Dey, J. Am. Chem. Soc. 2020, 142, 17312-17317

[10] Sonochemistry: from Basic Principles to Innovative Applications. Topics in Current Chemistry (2017), Eds G. Chatel, J. C. Colmenares, ISSN: 2365-0869 (Print) 2364-8961 (Online), Springer International Publishing Switzerland 2017.

[11] a) Y. T. Didenko, K. S. Suslick., Nature, 2002, 394-397, b) A. Henglein, Z. Naturforsch. B, 2004, 40 (1), 100-107.

[12] a) M. Abu-Dayeh Matouq, Z. A. Al-Anber, Ultrason. Sonochem., 2007, 14(3), 393-397; b) M. Faryadi, M. Rahimi, N. Moradi, S. Safari, Desalination Water Treat., 2015, 54(12), 3412-3421.

[13] R. Pflieger, T.Ouerhani, T. Belmonte, Sergey I. Nikitenko, Phys. Chem. Chem. Phys., 2017, 19, 26272-26279.

[14] a) L. H. Thompson, L. K. Doraiswamy, Ind. Eng. Chem. Res. 1999, 38 (4), 1215-1249; b) Y. Mizukoshi, H. Nakamura, H. Bandow, Y. Maeda, Y. Nagata, Ultrason. Sonochem., 1999, 6 (4), 203-209. 
[15] a) H. Nakui, K. Okitsu, Y. Maeda, R. Nishimura, J. Hazard. Mater., 2007, 146, 636-639; b) H. Nakui, K. Okitsu, Y. Maeda, R. Nishimura, Ultrason. Sonochem., 2007, 14 627-632.

[16] P. Neta, P. Maruthamuthu, P. M. Carton, R. W. Fessenden, J. Phys. Chem., 1978, 82 (17), 1875-1878.

[17] L. Huang, L. Li, W. Dong, Y. Liu, H. Hou, Environ. Sci. Technol. 2008 , 42 (21), 8070-8075.

[18] a) R. Kidak, N. H. Ince, Ultrason. Sonochem., 2006, 13 (3), 195-199 ; b) C. Petrier, M.-F. Lamy, A. Francony, A. Benahcene, B. David, V. Renaudin, N. Gondrexon, J. Phys. Chem. 1994, 98 (41), 1051410520 ; c) P. S.Bapat, P. R.Gogate, A. B.Pandit, Ultrason. Sonochem 2008, 15 (4), 564-570; d) T. Lesko, A. J. Colussi, M. R. Hoffmann, Environ. Sci. Technol. 2006, 40, 21, 6818-6823; e) W. Zheng, M. Maurin, M. A. Tarr, Ultrason. Sonochem, 2005, 12 (4), 313-317.

[19] C. Wu, A. De Visschera, I. D. Gates, RSC Adv., 2017, 7, 35776-35785.

[20] J. K. Niemeier, D. P. Kjell, Org. Process Res. Dev. 2013, 17, 1580-1590. 


\section{Entry for the Table of Contents}
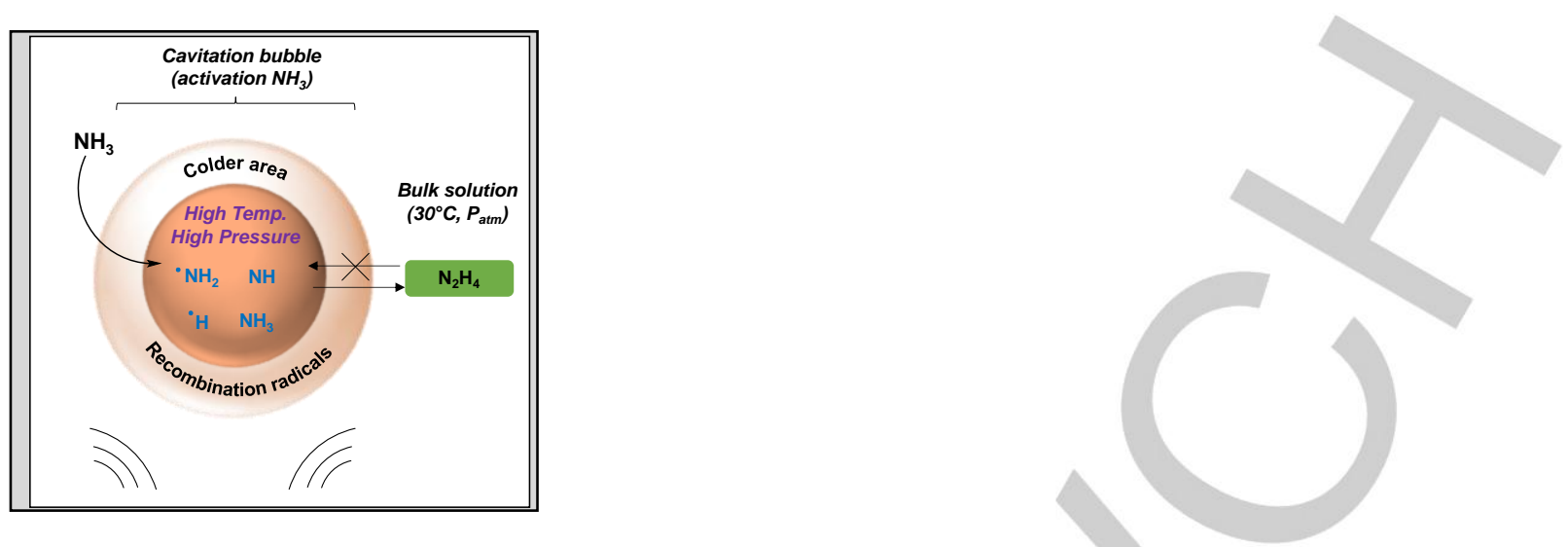

Cavitation bubbles act as micro-reactors to activate $\mathrm{NH}_{3}$, resulting in the formation of $\mathrm{NH}$ species that are further recombined to hydrazine at the bubble-liquid interface. One of the advantages of this technology is the compartmentation of the as-formed hydrazine in the bulk solution, maintained at only $30^{\circ} \mathrm{C}$, which limits its thermal degradation.

Institute and/or researcher Twitter usernames: ((optional)) 